\title{
Change the way of discipline, Fulfilling peer supervision - Exploration and Reflection on the Implementation of the Supervisory Function of the College Discipline Inspection Commission under the New Normal
}

\author{
Wang Yue, Gao Lingling \\ Yunnan Open University, Yunnan Vocational \& Technical College of National Defense Industry, \\ Kunming Yunnan, china, 65000
}

Keywords: Commission for Discipline Inspection; Peer supervision; University

Abstract: The Disciplinary Committee's supervision of party committees at the same level is the basic responsibility assigned by the party constitution in China. Under the current system, the Disciplinary Committee supervises the party committees at the same level and there are generally practical problems such as insufficient supervision, difficult implementation, and ineffective results. How to overcome the shortcomings of the Disciplinary Committee of the University to supervise the party committee at the same level and implement the inner-party supervision mechanism is a difficult task in front of the Disciplinary Committee at all levels under the new normal.

\section{Introduction}

In the 96-year history of the Communist Party of China, "anti-corruption" has been running through it. However, its intensity and breadth have never been so dense, lively and climax since the 18th National Congress of the Communist Party of China. The "tiger" that only fell into the horse became a topical feast for people to relax after a meal in the streets. In recent years, the exposure of college corruption cases has become a serious trend, mainly reflected in economic corruption, enrollment and corruption, infrastructure problems and research funding issues. The main targets of corruption are concentrated in party and government leadership. For example: Yan Jian, vice president of Zhejiang University, and An Xiaoyu, vice president of Sichuan University, and other serious violations. Anti-corruption is gradually becoming a "human tragedy" that is constantly being taken away by a "human comedy" from a distant view of high officials. The grim form reminds us that the construction of party style and clean government in colleges and universities has a long way to go. The Disciplinary Committee's supervision of party committees at the same level is one of the effective ways to prevent and cure corruption and to keep the Communists clean and honest. How to implement this inner-party supervision mechanism is a difficult task in the face of the discipline inspection and supervision department of the university under the new normal. 


\section{The Origin and Significance of "Same Level Supervision"}

"Same level supervision" is also called "same body supervision", which refers to the effective supervision of the Disciplinary Committee on the party's work style and clean government building at the same level party committees, especially the main leading members of the party committee at the same level. It is derived from the Constitution of the Communist Party of China and the Regulations on the Supervision of the Communist Party of China. Article 8 of the "Regulations on Inner-Party Supervision" clearly states that the party's disciplinary inspection committees at all levels are specialized agencies within the party's supervision. Perform the following duties in the supervision of the party: (1) Assisting the committees of the same party to organize and coordinate the supervision within the party, and organize the supervision and inspection of the supervision within the party; (2) Supervising the performance of duties and driving rights of party members and leading cadres. Article 44 of the revised Constitution of the Communist Party of China states: The main tasks of the party's disciplinary inspection committees at all levels are: Safeguard the party's statutes and other party statutes, check the implementation of the party's line, principles, policies, and resolutions, and assist the party's committees to strengthen the party's work style and clean government, and organize and coordinate corruption...Supervise the right to drive leading party members.

The "Decision of the Central Committee of the Communist Party of China on Several Major Issues Concerning Comprehensively Deepening Reform" adopted by the Third Plenary Session of the 18th CPC Central Committee proposed: "The Disciplinary Committees at all levels must fulfill their duties of assisting party committees in strengthening the building of party style and clean government and organizing and coordinating anti-corruption work, strengthen supervision over party committees at the same level, especially members of the Standing Committee, and give full play to the role of special organs within the party."

As far as colleges and universities are concerned, the Disciplinary Committee fulfills its supervisory function at the same level, which is of great significance:

Helping to create a politically ethical and ecological culture in colleges and universities, to create an academic atmosphere, and to ensure that colleges and universities "purify the land". At the same time, it has great practical significance for the in-depth development of the party's style and clean government and the "three strict and three real" educational activities.

It plays a very important role in improving the life of the party and improving the supervision mechanism. From the perspective of supervision, the best understanding of the party committee at the same level is the same as the disciplinary committee at the same level. Therefore, fulfilling the supervisory function of party committees at the same level plays a very important role in improving the inner life of the party and improving the supervision mechanism.

Helps prevent and prevent the emergence of corruption. The French enlightenment thinker Montesquieu said: "The right without restrictions will inevitably lead to corruption." This shows that corruption stems from the abuse of rights. In the big corruption cases in colleges and universities, the amount of corruption in design is huge. The root cause lies in the fact that rights are not bound and supervised.

\section{The University Commission for Discipline Inspection supervises the main problems faced by party committees at the same level}

Intra-party supervision is actually based on horizontal leadership at the same level, supplemented by vertical superior leadership. The Disciplinary Committees at all levels are working under the leadership of party committees at the same level, and are mainly responsible for party committees at the same level. Under such a system, it is difficult for the Commission for Discipline Inspection to 
effectively perform its duties of supervising party and government organizations and leading members at the same level. The specific performance is:

The supervisory subject is subject to the object, lacks independence, and is difficult to supervise. As a special supervisory organ within the party, the Disciplinary Committee of the University is affiliated to the work of the party committee at the same level, and lacks independence, making it difficult for the disciplinary committee to supervise. This actually makes the Disciplinary Committee's supervisory power subject to the executive power of the party committee. School supervision, auditing, finance and other supervision, discipline inspection cadre allocation, appointment and dismissal, and mobilization, the opinions of party committees at the same level play a leading role, and a series of issues such as staffing, financial funds, work and life treatment are mainly determined by party committees and administrators at the same level. This objectively makes it difficult for the disciplinary committee of the university to supervise the party committee at the same level, especially for the main leaders of the party committee at the same level.

The object of supervision is the leader of the supervisory body, and it is closely related and does not dare to supervise. The discipline inspection cadre (secretary) of the university is a member of the party committee. The secretary of the disciplinary committee at the same level of the university is only a member of the party committee at the same level. In the party committee, the party secretary is the squad leader, who holds the important rights conferred by the party and the people in the hands of the leadership team and the overall work. At the core, it plays a key role. From the perspective of understanding the problem, the team members have the most say in the performance of the top leaders, but from the perspective of implementation supervision, they are always under the leadership of the top leaders and do not dare to drive this right.

\section{Strengthening the effective measures of the discipline inspection committee of the university to supervise the party committee at the same level}

Implement the "vertical leadership model." That is, the Disciplinary Committee of the University is directly independent of the school by the vertical leadership of the Provincial Commission for Discipline Inspection. The political and economic treatment of the discipline inspection cadres has nothing to do with the school. In order to achieve effective supervision of the school party committee, it is necessary to handle the relationship between the Commission for Discipline Inspection and the party committee at the same level, and avoid the complete separation between the Disciplinary Committee and the party committee at the same level, so that the inter-party decision-making power and supervision power are interconnected and mutually balanced. Relationships are difficult to form. It is necessary to clearly stipulate that the discipline inspection cadres have the right to participate in all activities of the school, to attend the party committee, and all the resolutions made by the party committee without the participation of the discipline inspection cadres are invalid, so that the independence and authority of the discipline inspection commission can be increased. Solve the shortcomings of the Disciplinary Committee of the University to supervise the independence of party committees at the same level and the lack of authority.

Further improve the rules of family supervision and formulate rules for the supervision of operability. Although the Central People's Republic of China has successively promulgated the "Regulations on Disciplinary Actions of the Communist Party of China", "Regulations on the Supervision of the Communist Party of China", and "Regulations on the Protection of the Rights of Chinese Communist Party Members" But no system has yet been formed. Generally speaking, China's supervision legislation is still not perfect, and there is no special supervision and regulation, which leads to specific supervision activities without rules and rules, lack of maneuverability, and greatly affects the supervision of the supervisory body. The supervision within the party is a kind of 
legal supervision. This not only shows that the supervision within the party supervises the party committee's exercise of power according to law, but also means that the supervision within the party must be carried out according to law. A sound system of supervision and supervision is the basis for ensuring the effectiveness of supervision within the party.

Improve the quality of discipline inspection cadres. Supervisors are the specific implementers of supervision work, and improving the effectiveness of supervision depends largely on the quality of supervisors. At present, in view of the quality of the personnel engaged in the law enforcement team in China's supervision work, it should be said that most cadres can implement the relevant provisions of the Party Central Committee, adhere to the purpose of serving the people, obey the law, be loyal to their duties, be honest and clean, and enforce the law impartially. In the implementation of the Party's principles and policies and national laws and regulations, it has safeguarded the discipline of governance and made contributions to the construction of a clean government. However, from the deepening of reforms, the expansion of opening up, and the promotion of socialist modernization, the law enforcement cadres shoulder the historical mission under the new historical conditions and face the severe challenges. The quality of this team needs to be improved. First, we must improve the ideological and moral quality of discipline inspection cadres, strengthen the principle of party spirit, stress politics, be upright, and be a modern "baogong." Establish the image of disciplinary cadres in uprightness, integrity, justice and fairness. In actual work, we must work hard to overcome fear of offending people, dare not implement strong supervision; or give up supervision due to the intervention of leaders and friends; Even in some major principles such as safeguarding party discipline and protecting the interests of the country and the people, we cannot distinguish between the ideas of right and wrong. Rather, it is necessary to improve the knowledge level and business ability of discipline inspection cadres, strengthen business learning, constantly update their knowledge structure, and lay the foundation for solid discipline inspection work.

\section{References}

[1] Decision of the Central Committee of the Communist Party of China on Comprehensively Deepening Reforms on Several Major Issues [G], People's Publishing House, 2013

[2] Reflections on Establishing Effective Supervision Systems and Mechanisms [J], Theoretical Frontiers, 2001 (14)

[3] Inevitability and Path Analysis of Strengthening the Supervision Power of the Discipline Inspection Commission [J], Journal of the Party School of Shijiazhuang Municipal Committee of the Communist Party of China, 2014(3)

[4] How does the Disciplinary Committee supervise the members of the Standing Committee of the Party Committee at the same level [N], China Discipline Inspection Report, 2013 (3)

[5] Strengthening the Disciplinary Committee's analysis and suggestion on the ways and methods of supervision of party committee members at the same level [J], Huaihai Wenhui, 2013(5) 